\title{
KNOWLEDGE REPRESENTATION IN RUSSIAN AND EUROPEAN TRADITION
}

\author{
(C) V.V. Dobrova ${ }^{1}$, T. Koryakina Antunes ${ }^{2}$ \\ ${ }^{1}$ Samara State Technical University, Samara, Russia \\ ${ }^{2}$ CIPES - Center for Research in Higher Education Policies, Porto, Portugal \\ Original article submitted 01.11.2020 \\ Revision submitted 15.11.2020
}

- For citation: Dobrova V.V., Koryakina Antunes T. Knowledge representation in russian and european tradition. Vestnik of Samara State Technical University. 2020;(4):29-41. DOI: https://doi.org/10.17673/vsgtu-pps.2020.4.3

\begin{abstract}
Knowledge representation is a fundamental question in philosophy, pedagogy, linguistics, psychology and artificial intelligence. This paper examines the achievements in the field of creating knowledge-based systems that exist in Russian and European practice. We employed the methods of cross cultural content analysis and meta analysis to analyze various sources of information, to interpret definitions, and to increase the validity of the conclusions. The following problems are highlighted: the definition of knowledge and its types; the interplay between knowledge itself, its representation, and the physical world; approaches to knowledge representation; representation schemas for procedural and declarative knowledge types. The findings of the research illustrate that in Russian science, the problem of knowledge representation is associated with the problem of knowledge as such and its «representation» in our psyche, in contrast to European practice where the problem is considered to be purely applied. Theoretical contributions and practical implications discussed in the paper contribute to the problem of knowledge representation and prove the efficiency of combination of both discussed approaches.
\end{abstract}

Keywords: knowledge; representation; procedural knowledge; declarative knowledge; knowledge-based systems.

\section{ПРЕДСТАВЛЕНИЕ ЗНАНИЙ В РОССИЙСКОЙ И ЕВРОПЕЙСКОЙ НАУКЕ}

\section{(C) В.В. Доброва ${ }^{1}$, Т. Корякина Антюнес ${ }^{2}$}

${ }^{1}$ Самарский государственный технический университет, Самара, Россия

${ }^{2} \mathrm{CIPES}$ - Центр Исследований политики высшего образования, Порто, Португалия

Поступила в редакцию 01.11.2020

В окончательном варианте 15.11.2020

- Аля цитирования: Аоброва В.В., Корякина Антюнес Т. Представ^ение знаний в российской и европейской науке // Вестник Самарского Государственного Технического Университета. 2020. № 4(48). С. $29-41$. DOI: https://doi.org/10.17673/vsgtu-pps.2020.4.3

\footnotetext{
Представление знаний - фундаментальный вопрос философии, педагогики, лингвистики, психологии и искусственного интеллекта. В статье исследуются достижения в области создания систем, основанных на знаниях, существующие в российской и европейской практике. Мы использовали методы кросс-культурного контент-анализа и мета-анализа для анализа различных источников информации, интерпретации определений
} 
и повышения достоверности выводов. В статье рассматриваются такие проблемы как определение знания и его типов; взаимодействие между знанием, его представлением и физическим миром; подходы к представлению знаний; схемы представления для процедурных и декларативных типов знаний. Результаты исследования показывают, что в российской науке проблема представления знаний связана с проблемой знания как такового и его «репрезентации» в нашей психике, в отличие от европейской практики, где проблема считается чисто прикладной. Теоретические наработки и практические аспекты, обсуждаемые в статье, способствуют решению проблемы представления знаний и доказывают эффективность комбинации обоих обсуждаемых подходов.

Ключевые слова: знания; представление; процедурные знания; декларативные знания; системы знаний.

\section{Introduction}

The new realities of the socio-economic situation of human existence require the entire education system restructuring. The current challenges to the professional training of personnel for the future are associated with the increased requirements to their competence, that is, to the volume of knowledge and the ability to effectively apply it on the basis of processing and adaptation in accordance with the specified conditions. This task explains the basic contradiction of the modern educational system between the constantly increasing volume of knowledge and the traditionally limited time provided for its assimilation. To solve this contradiction we need to intensify the educational process and to increase the activity of the cognitive processes of students.

In Russian science, the problem of knowledge representation is associated with the problem of knowledge as such and its «representation» in our psyche. This means that all the connected problems are traditionally studied in the framework of epistemology, philosophy of knowledge, philosophy and history of science, and are also related to the problems of language and formal logic. In the European science knowledge representation is not a question of theory and is considered to be purely applied. Instead of discussing what knowledge is, how it differs from skills, how verbalized and non-verbalized knowledge relate, etc., the world builds complex systems based on knowledge and working in dialogue with a person, expanding his intellectual potential, etc. So, the content of the term "knowledge representation" in the Russian tradition continues to cover both theoretical and practical aspects; in European science, on the contrary, practical aspects prevail.

In the presented research, the achievements in the field of the practice of building knowledge-based systems that exist in Russian and European practice are discussed.

\section{Literature review}

The problem of knowledge representation is the oldest problem not only in artificial intelligence, but also in science and education in general. It is solved whenever it is necessary to transfer knowledge to someone or to teach how to apply and use it.

In recent decades the situation has been significantly influenced by an overabundance of various information provided to users of the virtual information environment. The ability to work with information is constantly becoming in demand in training.

Psychologists are actively studying the cognitive processes of perception and information processing that form the learning basis [1]. In pedagogy, there is a search 
for methods, techniques, technologies that allow for a short period of time to master the required amount of material, concentration or «compression» of information [2]. Thus, the theory of the stage-by-stage formation of mental actions [3], the methodology of pedagogical technology management [4], the concept of enlarging didactic units [5], the concept of thematic learning [6], the concept of concentrated learning [7], etc. were introduced. In cognitive linguistics and cognitive semantics such notions as language meaning, situations, events, context, linguistic and extra linguistic information, meaning structure were studied by I.M. Kobozeva [8], E.V. Paducheva [9], A. Wierzbicka [10], J. Barwise and M. Perry [11], R.P. Abelson and R. Schank [12], etc.

In order to understand the problem of knowledge representation and the nature of knowledge, the term «knowledge» should be clarified. In the Russian pedagogical literature, the term is used widely. The content of the term «knowledge» is one of the eternal problems, the solution of which requires further efforts.

As an example we can consider a number of statements related to the content of the term "knowledge":

- Knowledge is the totality of a person's ideas, in which the theoretical mastery of the subject is expressed;

- Knowledge is a form of the subject's activity, which reflects things and processes of objective reality;

- Knowledge as a necessary element and a prerequisite for a person's practical relationship to the world is the process of creating ideas, purposefully reflecting objective reality in the forms of his activity and existing in the form of a certain language system [13].

- Characteristic features and laws of the studied object fixed in cognitive image of a subject [14].

When comparing the definitions, it is clear that there is no component that emphasizes the role of knowledge as a necessary element and prerequisite for a person's practical relationship to the world, which separates the concepts of "sign system" and "activity for practical use" [15].

The European tradition defines knowledge as the natural outcome of understanding and using information within a particular context [16]. Thus we come across such definitions as '...the whole body of cognitions and skills that individuals use in order to solve problems...' [17, p.24], where the knowledge is viewed as pertaining specifically to decision-making tasks requiring the usage of context-specific information. Davenport and Prusak [18] suggest that knowledge is a collection of values and experiences, providing the individual with the ability to incorporate and evaluate new ideas and information. The more philosophical view is that knowledge can represent higher order concepts such as wisdom, insight, action, and resolve. Polanyi stated that knowledge is such a thing, that it is impossible to define fully, as 'we know more than we can tell' [19]. Knowledge can also be defined as being the accumulation and cultivation of information and data over time [20]. Given the multitude of knowledge definitions, it is perplexing to see that there is no overall theory of knowledge, as each theory of knowledge is grounded within specific situational contexts [21]. Thus, the common problem encountered with attempting to understand and "manage" knowledge, is in how it is principally defined and classified. 
The problem of knowledge representation requires an understanding of where the border lies between different types of knowledge. In Russian science the knowledge is classified according to the following groups:

- The knowledge that inductively comes from the natural observation and sense and motor experience, and the knowledge that are acquired from the theoretical explanation; that is everyday and scientific knowledge;

- The explicit (realized and communicated) and implicit knowledge;

- The procedural (how?) and declarative (what?) knowledge.

In European practice the knowledge is classifies as follows:

- Declarative knowledge that includes concepts, objects and facts expressed in declarative sentences, and also called descriptive knowledge.

- Procedural knowledge that are defined as imperative knowledge describing the knowing of how to do something. It includes rules, procedures, strategies, etc. and depends on the objective or task on which it should be applied.

- Meta-knowledge is the knowledge about the knowledge that is about the other knowledge type.

- Heuristic knowledge represents the knowledge of some experts in a field or subject.

- Structural knowledge that is the main knowledge to problem-solving. It presents relationships that exist between concepts or objects.

So the most discussed distinction in both scientific traditions is between declarative (that is "knowing that") and procedural (that is "knowing how") types of knowledge. Declarative knowledge can be described as factual knowledge, whereas procedural knowledge can be defined as the knowledge of specific functions and procedures to perform a complex process, task, or activity [22].

The variety of definitions which makes a general understanding of how and what knowledge is, can now be seen to be a complex affair. In order to understand these points of view, the key aspects of knowledge representation are highlighted further, i.e. the basics and the methods by which knowledge is manifested. It supports a general definition of knowledge, and as such is linked to the representation and usage of knowledge itself.

\section{Materials and Methods}

The presented research was carried out in 2015-2020 as a part of a complex study of knowledge representation integrating the methods and results of pedagogy, cognitive psychology, cognitive linguistics, artificial intelligence and philosophy. The cross cultural content analysis and literature review methods were used to analyze various sources of information; comparative and qualitative analysis were used to understand and interpret definitions; meta analysis was used to increase the validity of the conclusions.

\section{Results}

The topic of knowledge representation has recently received a new interpretation. In Russian science, the presentation of knowledge was previously considered to be only the initial stage of the cognitive process. In modern psychology, pedagogy, philosophy a different viewpoint has been formed, according to which "the formula that the idea (along with sensation and perception) belongs to the lowest, sensory level 
of cognition, opposed to thinking, is absolutely not sound" [23, p. 131]. The means of cognition is a cognitive model that allows construction, processing, storage, recoding, mutual transition of verbal and sign forms of knowledge representation [24]. In this sense the ultimate goal of any knowledge representation is to allow information to be efficiently structured, modified, and reasoned with. The paradigm "word, image and action" becomes the basic for the modern cognitive educational model construction. Cognitive scientists, educators, and psychologists include there cognitive practices with motivational, semantic, emotional, mental ways of understanding and conceptualizing the perceived information that are based on cognitive structures. Their significance is rather great as they can be applied to the construction, organization, and management of knowledge within and across many disciplines. Thus, cognitive practices are interpreted as the connection of cognitive procedures and of the structures of knowledge of various scientific fields. The importance of the cognitive model is great as the knowledge representation must be effective at representing the inquirer's knowledge, rather than describing the information itself. As a result, knowledge appears as an integrative image that unites the rational (the pattern of translation of a verbal-logical concept into an image), operational (the introduction of the mutual translation of one knowledge type into another (re-encoding)), and existential or anthropological (the connection with life-affirming meanings (value factor)). To implement this paradigm of knowledge is a strategic goal and a matter of a relatively distant perspective.

In European practice knowledge representation is based on Piaget's tradition of semiotic functions [25], where learning and thinking are considered to be a process of operating and using the systems of signs (images, language, gestures, or symbols). Such systems enable people to visualize and express their thoughts, ideas, feelings and subjective experiences. Thus, the idea of mental representations advanced to the most important concepts of cognitive science.

The research on knowledge representation in European tradition is based on the hypothesis that people when memorizing knowledge use specific propositions about the conceptual information that are inherent in the issue to be remembered. There is also the conception that information can be memorized by means of various images that correspond as analogues to the original perception process. This basic alteration can be widened by the third form of knowledge representation introduced in semiotics. Actually, the semiotic differentiation includes signs that are used as an index (e.g., red as a sign of danger), an icon (e.g., the line drawing of a figure), or a symbol (e.g., numerals, letters, mathematical symbols). Correspondingly, specialists in cognitive psychology often differentiate between "enactive" (activity-based), iconic, and symbolic types of knowledge representation [26].

The biological development of the central nervous system shows that people first develop the functions for motor skills, perception, and coordination. This can be referred to enactive representation as "a mode of representing past events through appropriate motor response ... Such segments of our environment - bicycle riding, tying knots, aspects of driving - get represented in our muscles, so to speak" [26, p. 2]. This enactive representation is considered to maintain its central significance as a sign function over the entire life.

The iconic knowledge representation corresponds to the idea of special encoding that means that the memory content is tend to retrieve in the same format as it 
was coded when learned. According to this, many psychologists underline the significance of iconic representation by highlighting the fact that it can be influenced by images and graphics. On the other hand, cognitive scientists [27] of the Würzburg School reject this idea of representing knowledge by visual means. This controversial argumentation became known as "imagery debate".

Finally, knowledge is represented by means of symbols. Human language is considered as symbolic because it is impossible to infer the signified ("a white liquid that cows produce") from the signifier (e.g., the sounds or letters $M+I+L+K$ ). By using linguistic means of expression, people can visualize thoughts, ideas, and feelings, that is to describe things that they can express only to a limited extent by other means. Thus, it's a unique human characteristic that they can express their own experiences through language. Concepts as the most general form of symbolic knowledge representation are categorizations of generalized abstractions that require the cognitive operators application for class formation and abstraction.

Modern cognitive science considers cognition and learning to be a complex process with many facets that include symbolic representations of objects and events that are not immediately present but exist only in imagination [22]. Most cognitive researchers agree that cognition and learning take place when using mental representations in which an individual organizes symbols of thought or experience in such a way that they effect a systematic representation of this experience or thought as means of understanding it [28]. Seel describes the knowledge representation function by distinguishing three zones: W (the object zone as part of the physical world), $\mathbf{K}$ (the knowledge zone), and $\mathbf{R}$ (the zone of knowledge representation) [28, p. 17]. The interplay between the mentioned zones is presented in Fig. 1.

Fig. 1 shows the interplay between knowledge itself, its representation, and the physical world where the two classes of functions can be seen: (1) $f_{\text {in }}$ is the function of the internal representation (internalization) of the world objects, and (2) $f_{\text {out }}$ is the function for the external re-representation (externalization) back to the physical world.

A refinement of this representational concept is presented by Merali [29], who suggests that knowledge also exists through continuous generation and self-organising

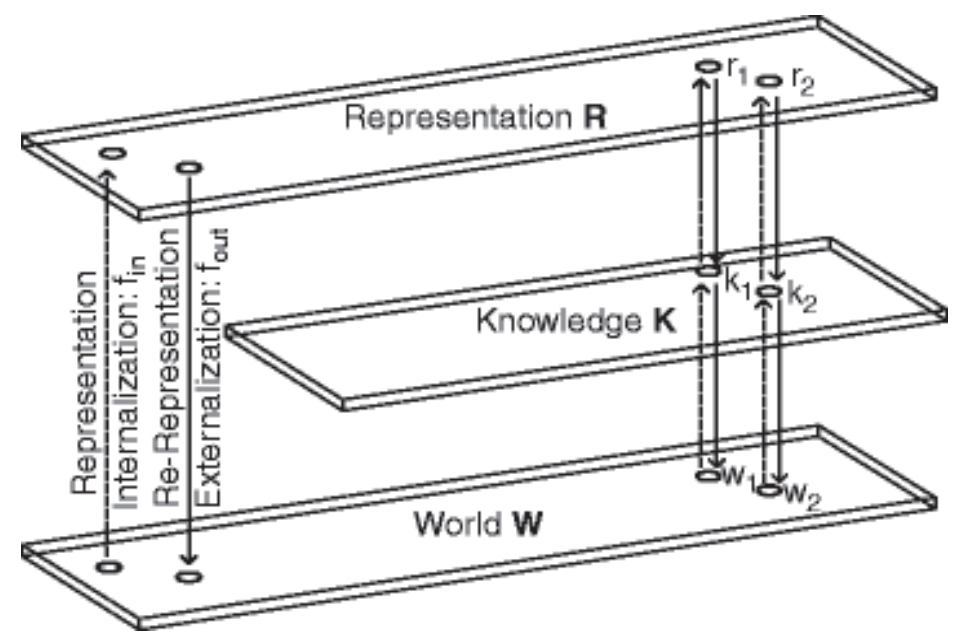

Fig. 1. Knowledge Representation (from [22]) 


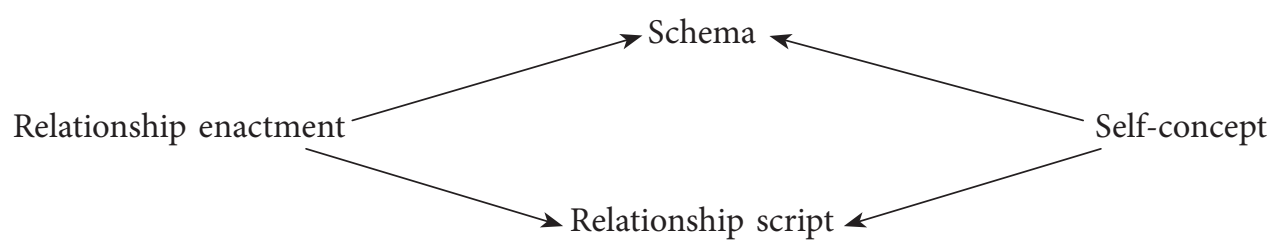

Fig. 2. The Cognitive Congruence Framework (from [29])

behaviour. With the help of the Cognitive Congruence Framework (Fig. 2) he defines a collection of beliefs and relationships (schema); an identity (self-concept); a set of rules and premises that bound the knowledge (relationship script); and the manner by which such knowledge relationships are enabled (relationship enactment).

The approach taken by Merali helps to overcome many of the abstract arguments as it suggests that knowledge is represented best when all the knowledge components somehow reinforce their interrelationships by both their existence and their interaction level. Besides it should be mentioned that without a given representation, or method of relating information to a recipient, knowledge cannot be produced from merely information alone [30].

In this regard, different models and means of knowledge representation have been developed. Moreover, they continue to be developed. There are mainly four approaches to knowledge representation in European tradition and the Russian representation models are mainly based on them:

1. Simple relational knowledge is the simplest way of storing facts with the use of the relational method where every fact about the object is systematically placed in columns. This knowledge representation approach is used in database systems in which the different entities relationship is represented.

2. Inheritable knowledge is used when all data should be stored into a hierarchy of classes. This approach contains inheritable knowledge that shows a relation between instance and class where an individual frame represents the collection of characteristic attributes and its values.

3. Inferential knowledge is represented in the form of the formal logics. It can be used to derive more facts.

4. Procedural knowledge approach uses codes and small programs that describes how to do this or that specific thing, and how to proceed.

In cognitive sciences usually a distinction is made between representation schemas that refer to declarative and procedural knowledge.

The idea of representation of declarative knowledge is based on the assumption that one considers the issue of representation largely independent on the methods of knowledge application. The declarative knowledge is considered to be a set of facts that can be represented as data structure. A representation schemes taxonomy presented by Mylopoulos and Levesque [31] grounds on the assumption that the world is a collection of individuals that are interconnected by manifold relationships. This collection of all individuals and their relationships at any one time and in any world constitutes a state, but the state can be transformed causing the creation of individuals or changing the relationships between them. Depending on whether the central point for a representation scheme is assertions about states or individuals and 
their relationships, a distinction is made between logical representation schemas and semantic networks.

As examples of logical representation schemas the knowledge bases constructed on the first-order logic basis can be considered [32]. Statements on the world domain to be represented are translated into the formulas that permit conclusions. Such a representation schema form clearly presupposes the appropriate inference rules that should also be available. The semantic networks are more popular for declarative knowledge representation. In its most primitive form a semantic network represents knowledge as a collection of objects (the so-called nodes) and binary associations (that are directed labeled edges); the former stands for individuals (or some sort of concepts), and the latter stands for binary relations over these. One more form of declarative knowledge representation is Schank's Conceptual Dependency Structure [12] that focuses on conceptualizations attributing cases to actions. And finally, frames should be mentioned in the context of declarative knowledge representation, though their aim is to combine the declarative and procedural knowledge representations. Furthermore, frames are usually mentioned as a representation schema allowing to make a compound of semantic networks and productions.

Depending on whether the state transformations is the starting point for a representation schema, the application of semantic networks or logical representation schemas is limited and it demands another representation type. Clearly, the most widely used procedural representation schemas operate with productions and production systems.

Logical representation is a language with some concrete rules which deals with propositions and has no ambiguity in representation. Logical representation means drawing a conclusion based on various conditions. This representation lays down some important communication rules. It consists of precisely defined syntax and semantics which supports the sound inference. Each sentence can be translated into logics using syntax and semantics.

Despite such a variety of means of representing knowledge, the national tradition also distinguishes three main models of knowledge representation: logical, network and production [33-35]. Representatives of pedagogy, psychology and cognitive linguistics offer a number of cognitive structures, using which it is possible to represent the content of education in the form of hierarchical schemes. However, it should be noted that Russian scientists understand the general strategic task in the sphere of constructing the education content as the theoretical one, and focus mainly on presenting the organic connection of the cognitive, emotional and cultural foundations in teaching. It implies a number of the most urgent intermediate tasks.

The first of them is the relationship problem between verbal and visual knowledge forms. Solving it, the scientists proved the priority of visual thinking over the verbal one. Thus the following arguments can be mentioned: first, visual thinking allows you to perceive information almost instantly; second, the impact of visual information is deeper than verbal; thirdly, visual means contribute to a more holistic perception of the object; fourthly, the visual presentation of information is the primary means of communication in mass culture [36, p. 28]. The second task is focused on the differentiation of the concepts of educational, scientific and academic knowledge in the pedagogical and psychological research literature and in studies 
on the philosophy of education and cognitive processes. These types of knowledge can vary in goals, objectives and what's more means of construction. In pedagogy today, a mechanism for translation of general theoretical provisions into the sphere of educational and cognitive activities is being formed. This mechanism can be described as the cognitive structures of knowledge and specific methods of cognitive actions. The third educational task is directed to working with educational text. The methods of rational design of educational texts are based on semantic structures, subject-predicate forms of text communication, logical connections, didactic methods and techniques, various scientific theoretical schemes and methods, etc. This interaction of didactic and methodological signs is considered to be a specific sign of educational knowledge. In the construction of cognitive models for the learning content, scientists introduce conceptual content, logical instrumental and didactic materials. The theoretical and practical bases, development of various conceptual models and initial categories of the education content in science are referred to the philosophy of education, that makes it possible to clearly highlight the specifics of educational knowledge.

In foreign practice, more attention is paid in this regard to practical problems, namely the development of a methodology [37], a practice-oriented concept [38], cognitive means (multidimensional cognitive models) [39], principles [40], criteria and mechanisms for selecting educational information, recommendations for the practical application of cognitive technologies in creating educational literature, etc.

\section{Discussion and conclusions}

The methods of construction and the forms of knowledge representation developed in pedagogy, cognitive science, psychology, linguistics, philosophy, computer science and artificial intelligence can significantly increase the efficiency of cognitive processes interpretation, and bring them to the level of innovative intellectual technologies.

The following topics have already been studied: theoretical issues related to the nature of knowledge and the role of language in the process of acquiring and fixing knowledge in our psyche, to the transformation of knowledge into a form that is transmitted to the outside and the possibilities of verbalizing knowledge, to the role of language structures in the process of acquiring knowledge, to the establishment of boundaries between knowledge and skills. As well as practical issues: the process of assimilating specific knowledge, the relationship between linguistic and cognitive structures, databases, entering knowledge into a computer and interacting with it. Though the focus of the presented research was purely explanatory in nature, it was aimed to extend the boundaries of knowledge, and also to show that to intensify and simplify knowledge presentation and acquisition we need to develop new pedagogical technologies and methods on the basis of knowledge representation schemes suggested in Russian and European practices and combine the theoretical and practical findings of pedagogy, psychology, philosophy, linguistics, IT and other cognitive sciences. Such new technologies should enable to broaden the volume of the acquiring knowledge without extra time, and to integrate learning goals to the individual students' abilities as well as to include the problem learning to the education process. The problem of theoretical foundation of such new educational technologies and their practical realization is one of the relevant topics to be discussed. 


\section{REFERENCES}

1. Kolodochka T.N. Freimovoe obuchenie [Frame-based learning]. Shkol'nye tekhnologii [School technologies]. № 1. 2005. Pp. 140-142.

2. Malyazina M.A., Kotova S.A. Vklyucheniye freymovogo obecheniya v praktiku prepodavaniya pedagogicheskih discipline $\mathrm{v}$ vysshey shkole [Introduction of frame learning to the practice of pedagogical disciplines teaching in high school]. Pedagogicheskiy zhurnal [Pedagogical journal]. Vol. 7. № 2A. 2017. Pp. 188-198.

3. Talyzina N.F., Volodarskaya I.A., Butkin G.A. Usvoyeniye nauchnyh poniatiy v shkole [Acquisition of scientific terms at school]. Moscow, 2017. 114 p.

4. Monakhov V.M. Razrabotka prognosticheskoy modeli razvitiya teorii obucheniya dlya IT obrazovaniya [Development of prognostic model of education theory for IT learning]. Sovremenniye informatcionniye tehnologii i IT obrazovaniye [Modern information technologies and IT education]. Issue 14. Vol.2. Moscow, MSU. 2017. Pp. 111-121.

5. Erdniyev P.M. Ukrupneniye znaniy kak usloviye radostnogo ucheniya [Enlargement of knowledge as the condition of happy learning]. Nachal'naya shkola [Primary school]. № 11. 1999. Pp. 4-12.

6. Kabkov P.K. Kontceptciya tematicheskogo obucheniya [Concept of theme learning]. Moscow, MSU. 1994. 64 p.

7. Lukyanova V.S., Ostapenko A.A. Obrazovatel'naya kontceptciya Azovskogo eksperimental'nogo sotcial'no pedagogicheskogo kompleksa [Educational concept of Azov experimental social and pedagogical complex]. Azov, 1996. 17 p.

8. Kobozeva I.M. Lingvisticheskaya semantika [Linguistic semantics]. Moscow, 2000. 223 p.

9. Paducheva, E.V. Vyskazyvaniye I ego sootnesennost s deystvitelnost'yu [Utterance and its connection to reality]. Moscow, 2004. 224 p.

10. Wierzbicka A. Language and Metalanguage: Key Issues in Emotion Research. Emotion Review. №1. 2009. Pp. 3-14. DOI: 10.1177/1754073908097175.

11. Barwise J., Perry M. Situations and Attitudes. Cambridge (Mass.): MIT Press, 1983. Pp. 264-265.

12. Abelson R.P., Schank R. Scripts, Plans, Goals and Understanding: an Inquiry into Human Knowledge Structures. New York, Hillsdale. 1977.

13. Kopnin V.P. Logicheskiye osnovy nauki [Logical basis of science]. Kiev, 1968. 35 p.

14. Zotova A.F., Mironova V.V., Razina A.V. Filosofiya [Philosophy]. Moscow, 2019. 672 p.

15. Romantsova M.G., Ledvanova M.Y., Sologub T.V. Didaktika I kompetentnost'v professional'noy deyatelnosti prepodavatelya meditcinskogo vuza I kolledzha [Didactics and competence in the professional activity of teachers of medical institutes and colleges]. Moscow, Academy of Natural Sciences. 2010.

16. Sharif A.M. Knowledge representation within information systems in manufacturing environments. Department of Information Systems and Computing, Brunel University, 2004. 251 p.

17. Probst G., Raub S., Romhardt K. Managing Knowledge: Building Blocks for Success. John Wiley: Chichester, UK, 2001.

18. Davenport T.H., Prusak L. Working knowledge: how organizations manage what they know. Harvard Business School Press: Boston, MA, USA,1998.

19. Polanyi M. The Tacit Dimension. Doubleday-Anchor: NY, New York, USA,1967.

20. Leonard-Barton D. Wellsprings of Knowledge: Building and Sustaining the sources of Innovation. Harvard Business School Press: Boston, MA, USA, 1995.

21. Wiig K.M. Knowledge Management Methods: Practical Approaches to Managing Knowledge. Schema Press: Arlington, TX, USA, 1995.

22. Seel N.M. Encyclopedia of the Sciences of Learning. Springer, Boston, MA, 2012. DOI: https://doi.org/10.1007/978-1-4419-1428-6_875

23. Lektorskiy V.A. Epistemologiya klassicheskaya I neklassicheskaya [Classical and non-classical epistemology]. M, 2001. 256 p. 
24. Minitskiy N.I. Sovremenniye paradigm konstruirovaniya soderzhaniya istoricheskogo obrazovatel'nogo znaniya [Modern paradigm of construction of historical educational knowledge]. Крыніцазнаўства і спецыялыныя гістарычныя дысиыпліны : навук. зб. Вып. 6. Мінск : БДУ, 2011.Рp. 29-34.

25. Piaget J. Construction of reality in the child. London: Routledge \& Kegan Paul, 1957.

26. Bruner J.S. The course of cognitive growth. The American Psychologist. №19. 1964. Pp. 1-16.

27. Pylyshyn Z. Computation and cognition: Toward a foundation for cognitive science. Cambridge, MA: MIT Press, 1984.

28. Seel N.M. Weltwissen und mentale Modelle. Göttingen: Hogrefe, 1991.

29. Merali Y. The role of boundaries in knowledge processes. European Journal of Information Systems. № 11. 2002. Pp. 47-60.

30. Capurro R. What is information science for? A philosophical reflection. In: Conceptions of Library and Information Science. Historical, empirical and theoretical perspectives. Taylor Graham: London, 1992. Pp. 82-98.

31. Brodie M.L., Mylopoulos J., Schmidt J.W. On conceptual modelling. Perspectives from artificial intelligence, databases, and programming languages. New York: Springer, 1984. Pp. 3-17.

32. Barsky A.B. Iskusstvenniy intellect i logicheskiye neyronniye seti [Artificial intelligence and logical neuro nets]. Saint-Petersburg, 2019. 360 p.

33. Leshcheva I.A. Praktichesliy podhod k sozdaniyu I napolneniyu baz znzniy ontologisheskogo tipa: problem i vyzovy [Practical approach to creation and filling of knowledge bases of ontological type: problems and challenges]. Inginiring predpriyatiy I upravleniye znaniyami [Engineering of enterprises and knowledge management]. REU im. GV Plekhanov, 2018. Pp. 194-201.

34. Zagorul'ko Y.A. Sovremenniye sredstva formalizatcii semantiki oblastey znaniy na osnove ontologiy [Modern means of formalization of fields of knowledge semantics on the ontology basis]. Informatcionniye i matematicheskiye tehnologii $v$ nauke I upravlenii [Information and mathematic technologies in science and management]. № 3 (11). 2018. Pp. 27-36.

35. Stankevich L.A. Intellektual'nye sistemi i tehnologii [Intellectual systems and technologies]. Moscow, 2017. 397 p.

36. Rozin V.M. Vizual'naya kul'tura i vospriyatiye. Kak chelovek vidit I ponimayet mir. [Visual culture and perception. How a man sees and understands the world]. Moscow, 1996. 224 p.

37. Hardarson A. Aims of Education: How to Resist the Temptation of Technocratic Models. Journal of Philosophy of Education. Vol. 51. № 1. 2017. Pp. 59-72.

38. Henning C.A., Ewerth R. Estimating the information gap between textual and visual representations. IJMIR. № 7(1). 2018. Pp. 43-56.

39. Nguyen H.D., Do N.V., Tran N.P., Pham X.H. Criteria of a knowledge model for an intelligent problems solver in education. Proceedings of 2018 10th IEEE International Conference on Knowledge and Systems Engineering (KSE 2018). Ho Chi Minh City, Vietnam, 2018. Pp. 288-293.

40. Paulheim H. Knowledge graph refinement: a survey of approaches and evaluation methods. Semantic Web Journal. № 8 (3). IOS Press, 2017. Pp. 489-508.

\section{Список литературы}

1. Колодочка Т.Н. Фреймовое обучение. // Школьные технологии. № 1, 2005. С. 140-142.

2. Малязина М.А., Котова С.А. Включение фреймового обучения в практику преподавания педагогических дисциплин в высшей школе. // Педагогический журнал. Том 7, № 2A, 2017. C. $188-198$.

3. Талызина Н.Ф., Володарская И.А., Буткин Г.А. Усвоение научных понятий в школе. Учебное пособие. М., 2017. 114 с. 
4. Монахов B.M. Разработка прогностической модели развития теории обучения для ИТ образования. // Современные информационные технологии и ИТ-образование. М., МГУ, вып. 14, том 2, 2017. С.111-121.

5. Эрдниев П.М. Укрупнение знания как условие радостного учения.// Начальная школа. № 11, 1999. С. 4-12.

6. Кабков П.К. Концепция тематического обучения. Постановка дидактических задач. Учебное пособие. М.: МГТУ ГА, 1994. 64 с.

7. Лукьянова В.С., Остапенко А.А. Образовательная концепция Азовского экспериментального социально педагогического комплекса. Азов, 1996. 17 с.

8. Кобозева И.М. Лингвистическая семантика. М., 2000. 223 с.

9. Падучева Е.В. Высказывание и его соотнесенность с действительностью. М., 2004. 224 с.

10. Wierzbicka A. Language and Metalanguage: Key Issues in Emotion Research.// Emotion Review, 1, 2009. Pp. 3-14. DOI: 10.1177/1754073908097175.

11. Barwise J., Perry M. Situations and Attitudes. Cambridge (Mass.): MIT Press, 1983. Pp. 264-265.

12. Abelson R.P., Schank R. Scripts, Plans, Goals and Understanding: an Inquiry into Human Knowledge Structures. N.Y.: Hillsdale, 1977.

13. Копнин В.П. Логические основы науки. Киев, 1968. 35 с.

14. Зотова А.Ф., Миронова В.В., Разина А.В. Философия. М., Проспект, 2019. 672 с.

15. Романциова М. Г., Ледванова М. Ю., Сологуб Т. В. Дидактика и компетентность в профессиональной деятельности преподавателя медицинского вуза и колледжа. Руководство для преподавателей. М., Академия Естествознания, 2010.

16. Sharif A.M. Knowledge representation within information systems in manufacturing environments. Department of Information Systems and Computing, Brunel University, 2004. 251 p.

17. Probst G., Raub S., Romhardt K. Managing Knowledge : Building Blocks for Success. John Wiley: Chichester, UK, 2001.

18. Davenport T. H., Prusak L. Working knowledge : how organizations manage what they know. Harvard Business School Press: Boston, MA, USA,1998.

19. Polanyi M. The Tacit Dimension. Doubleday-Anchor: NY, New York, USA,1967.

20. Leonard-Barton D. Wellsprings of Knowledge : Building and Sustaining the sources of Innovation. Harvard Business School Press: Boston, MA, USA, 1995.

21. Wiig K.M. Knowledge Management Methods: Practical Approaches to Managing Knowledge. Schema Press: Arlington, TX, USA, 1995.

22. Seel N.M. Encyclopedia of the Sciences of Learning. Springer, Boston, MA, 2012. DOI: https://doi.org/10.1007/978-1-4419-1428-6_875

23. Лекторский В. А. Эпистемология классическая и неклассическая. М., Эдиториал УРСС, 2001. $256 \mathrm{c}$

24. Миницкий Н.И. Современные парадигмы конструирования содержания исторического образовательного знания (от теории познания к интеллектуальным технологиям). // Крыніцазнаўства і спецыяльныя гістарычныя дысцыпліны : навук. зб. Вып. 6. Мінск : БДУ, 2011. С. 29-34.

25. Piaget J. Construction of reality in the child. London: Routledge \& Kegan Paul, 1957.

26. Bruner J. S. The course of cognitive growth // The American Psychologist, 19,1964. Pp. 1-16.

27. Pylyshyn Z. Computation and cognition: Toward a foundation for cognitive science. Cambridge, MA: MIT Press, 1984.

28. Seel N. M. Weltwissen und mentale Modelle. Göttingen: Hogrefe, 1991.

29. Merali $Y$. The role of boundaries in knowledge processes. // European Journal of Information Systems, 11, 2002. Pp. 47-60. 
30. Capurro R. What is information science for? A philosophical reflection. // Conceptions of Library and Information Science. Historical, empirical and theoretical perspectives. Taylor Graham: London, 1992. Pp. 82-98.

31. Brodie M. L., Mylopoulos J., Schmidt J. W. On conceptual modelling. Perspectives from artificial intelligence, databases, and programming languages. New York: Springer, 1984. Pp. 3-17.

32. Барский А.Б. Искусственный интеллект и логические нейронные сети. СПб.: ИЦ Интермедия, 2019. 360 с.

33. Лещева И. А. Практический подход к созданию и наполнению баз знаний онтологического типа: проблемы и вызовы. // Инжиниринг предприятий и управление знаниями. М., РЭУ им. ГВ Плеханова, 2018. С. 194-201.

34. Загорулько Ю.А. Современные средства формализации семантики областей знаний на основе онтологий. // Информационные и математические технологии в науке и управлении. № 3 (11), 2018. С. 27-36.

35. Станкевич Л. А. Интеллектуальные системы и технологии : учебник и практикум для бакалавриата и магистратуры. М., Юрайт, 2017. 397 с.

36. Розин В. М. Визуальная культура и восприятие. Как человек видит и воспринимает мир. М., Эдиториал УРСС, 1996. 224 с.

37. Hardarson A. Aims of Education: How to Resist the Temptation of Technocratic Models. // Journal of Philosophy of Education. Vol. 51, № 1, 2017. Pp. 59-72.

38. Henning $C$. A., Ewerth R. Estimating the information gap between textual and visual representations. // IJMIR, 7(1), 2018. Pp. 43-56.

39. Nguyen H. D., Do N. V., Tran N. P., Pham X. H. Criteria of a knowledge model for an intelligent problems solver in education. // Proceedings of 2018 10th IEEE International Conference on Knowledge and Systems Engineering (KSE 2018). Ho Chi Minh City, Vietnam, 2018. Pp. 288-293,

40. Paulheim $H$. Knowledge graph refinement: a survey of approaches and evaluation methods. // Semantic Web Journal, 8 (3), IOS Press, 2017. Pp. 489-508.

Information about the authors

Victoria V. Dobrova, Cand. Psych. Sci., Associate Professor, Head of Foreign Languages Department. Samara State Technical University. Samara, Russia. E-mail: victoria_dob@mail.ru. ORCID 0000-0002-3037-4797

Tatiana Koryakina Antunes, $\mathrm{PhD}$ in Social Sciences, Researcher. Center for Research in Higher Education Policies (CIPES). Matosinhos, Porto, Portugal. E-mail: tatianakor@hotmail.ru. ORCID 0000-0001-7539-249X

Информаиия об авторах

Виктория Вадимовна Доброва, кандидат психологических наук, доцент, заведующий кафедрой «Иностранные языки». Самарский государственный технический университет. Самара, Россия. E-mail: victoria_dob@mail.ru. ORCID 0000-0002-3037-4797

Татьяна Корякина Антюнес, PhD Социальных наук, исследователь. Центр Исследований политики высшего образования (CIPES). Матосинхос, Порто, Португалия. E-mail: tatianakor@hotmail.ru. ORCID 0000-0001-7539-249X 